\title{
The Loan Market in Lithuania: Evaluation of Developments in 2002-2012 Years
}

\author{
Larisa Belinskaja \\ Assoc. Professor, Dr. at Vilnius University, Lithuania \\ Author: E-mail: larisa.belinskaja@ef.vu.It
}

\section{Doi:10.5901/ajis.2013.v2n8p171}

\section{Abstract}

Historically and for a long, banks activity is more connected with providing loans than with borrowings for their own purposes (T. Mayer, J.S. Duesenberry, R.Z. Aliber, 1990). The object of the article is Lithuanian loans market. The task of the article is to present analysis and evaluation of loan market developments during 2002-2012 years. Commercial banking activity in Lithuania has its old tradition. State bank „Bank Polski i Litewski“ was found in 1792. This bank had it's affiliates in Vilnius, Gardinas and Minsk (now - Belorus). In 1795 when Lithuania and Poland third time was divided, and Lithuania lost statehood and independent, as well as a possibility to create and develop own finance and credit system (O. Buckiūnienè, 2011).Lithuanian loans' market is analyzed using related scientific-theoretical literature about peculiarities of loans market, also statistical data and official facts from the reports of Bank of Lithuania and State Statistical Department in ten years' (2002-2012). The main factors influenced on loan market developments are GDP per capita, inflation, unemployment, middle average salary, interest rate and volume of deposits in a certain periods etc. Various indicators of loans market development are calculated and presented in article - dynamics according to various factors (dynamics of loans and GDP, dynamics of interests, duration, currency, purpose of loans, mortgage loans proportion), as well as sudden changes in indicators, quality and risk of loans portfolio is evaluated, reasons of market boom and factors influencing on its development are clarified, as well as problems and tendencies are evaluated. There have been employed following methods: Lithuanian and foreign theoretical scientific literature analysis; filling of, sorting out and calculation of statistical data and evaluation of statistical facts; statistical facts comparative and retrospective analysis. After making analysis of loans market, there have been made following conclusions: in 2002 - 2005 loans market was growing because of economical fast growing and overestimated optimism for future welfare, there was loans' boom in the state during 2002 - 2008 years, although because of financial crisis from 2009, loans' market recession happened; 2011-2012 is a period of loans' market stability; from 2014, a growth of loans' market is forecasted, however it is very important, that it would be temperate after all.

Keywords: loan, credit risk, banks, financial indicators.

\section{Introduction}

The story of the Baltic State's economic development since regaining independence in 1990 seems almost too selfevident to tell. The small open economies were flushed with foreign capital, became overleveraged, and are now paying the price. After exhibiting double-digit growth rates during the past decade, the 'Baltic tigers' have also become recordsetters in the negative direction, being the first countries to enter a deep economic crisis in 2009.

In fast growing economies a creation and successful development of businesses is the most important challenge for internationalized world economy. Only few entrepreneurs can provide these tasks at their own account, many others have to use credit resources as for business creation as for business development and supporting its financial stability. Every business is influenced by many risks, but the most important from them is credit risk. For this reasons banking sector's influence on economic stability and growth is constantly increasing. Credit risk management problems are under most urgent discussions worldwide and in small economies like Lithuanian and not only because of recent financial crisis (E. I. Altman et al., 1998 2002, 2003); J. Bessis (2002); Bonner E. A. (2008); A. Brown (2004); J. Colquitt (2007); D. Duffie et al. (2003); L. Dzidzevičiūtè (2010); F. Jasevičienè et al. (2000); Kancerevyčius (2004); T. Mayer et al. (1990); Reinhart, C.M., Rogoff, K.S. (2008), Rouz P. S. (1993); A. M. Santomero (1997); V. Valvonis (2006); Vaškelaitis (2003); N. Wagner (2008) etc.

Even commercial banking activity in Lithuania has its comparatively old tradition (though first commercial credit operations started to develop in Renaissance Italy, the first commercial banks was established in European countries in XVII century, and the first commercial bank in Lithuania started to operate in 1792), only after restoration of Independence in Lithuania in 1990 banking sector began to develop under the finance market common practice and rules. Commercial banks in Lithuania rely upon traditional banking activity, i.e. mostly lending credit resources in internal 
market. From this point of view banking sector in Lithuania during the latest years of developments experienced almost all possible stages comparing to world finance market's history and in a very short period indeed, only in 20 years formatted its legal environment, licenced first commercial banks, experienced internal banking crisis in 1995 accompanied by 14 banks bankrupts, when that period loan's interest rate exceeded 150\%, after observed fast growing and calculated huge profits in correspondance with fast growing Lithuanuan economy till 2007 and suffered from consequences of world financial crisis from 2008 till now. In recent period, 2 of the biggest Lithuanian commercial bank's - Snoras and Ūkio bankas - activity have been suspended in 2012-2013 with subsequent revocation of its licence. For all these reasons is very important to analyze situation at credit market taking into account the latest 10 years period as especially in this period credit market in Lithuania was developing under the rules, accountancy principles and supervision system corresponding to the most financial markets in the world. Also such analysis reveals so called bank's "greed for profit" which promote them to take wrong decisions in lending money and non proper credit risk management policy in different stages of economic development.

\section{Loans' importance for functioning of finance market}

Loan and credit are quite closed notions. Shortly, in a narrow sence credit means related obligations and loan means transaction contract. Loans are a source for credit risk in such frames and taking into account that in research period loans have been and still are a dominated part of Lithuanian bank's assets - almost 70\% in average during 2002-2012 according Lithuanian Bank (LB) data - so credit risk is the most important and dangerous risk for Lithuanian banking sector.

Different authors stress different functions of loans in economy - distributing, replacement, control, current assets turnover acceleration, acceleration of the process of concentration of capital, turnover of goods acceleration functions etc. (Aleknevičienè, 2005; Bessis, 2002; Bikas, 2013; Bonner, 2008; Caouette et al., 1998; Juozaitiené, 2000; Mituziené 2005; Nešitoj 2007; Vaškelaitis, 2003; Valvonis, 2004 and oth.), but mostly of them insist upon 2 main functions of loans distributing and control.

Banks giving loans for private and commercial clients taking credit risk which can be divided into separate elements - loan's failure to return, non-payable interest rate, breaking of terms for loan's and/or interest rate paying. Due to these separate elements credit risk assessment and management also has different stages and features in every stage - beginning from evaluation of borrower's possibilities to take loan, then to return loan, and later to pay interest rate and/or loan in time according the contract. Also there are differences in credit risk between different categories of loans: corporate, mortgage, consumer and export loans.

In literature there are relatively broadly described consequences of rapid liberalization of financial markets, when increased supply determines the growth of prices of separate assets, what hardly can be explained by fundamental factors (Kindleberger et al, 2005). As an example of it could be capital markets' value enlargement that could be explained by optimistic expectations (not real value). Another example - phenomenon of real estate market as an object for safe investment, it should be noted that duration the housing price declines is quite long-lived, averaging roughly six years (Reinhart and Rogoff, 2008; Belinskaja, Rutkauskas, 2007). Real estate market price bubbles is possible to keep as one from the models of the financial pyramids as a particular case (Girdzijauskas, 2005, 2006). Banks should be more demanding in real estate loan's regulations as many countries loan markets have a concentration in such type of loans. So, banker's attitude to borrowing in this sector of loans could cause a cyclical behaviour and real estate market price bubbles (Panagopoulos, Vlamis, 2009).

Therefore, analyzing and evaluating loan market as the most important part of finance market which in turn guaranty functioning and stability of all economy, especially in new growing economies as Lithuania belongs, remains urgently relevant.

\section{Analysis and evaluation of Loan market in Lithuania in 2002-2012 years}

Overview and analysis of loan market in Lithuania is evaluating in 20002-2012 years. To evaluate qualitative and quantitative developments of loan's market in Lithuania the main related indicators are observed as dynamics of loans according a various criteria (category of clients, currency's interest rates, type of economic activity), ratio of special technical provisions and loan portfolio, ratio of special technical provisions and customer loan portfolio, ratio of special technical provisions and mortgage loan portfolio, ratio of special technical provisions and assets, dynamics of GDP and Loan's Portfolio etc. The main sources of statistical data are official information of Bank of Lithuania and State Statistical 
Department. All Pictures presented below are composed by author using these official data and information.

Dynamics of total Loans shows not only changes in tendencies of its growth, but also helps to look up bank's credit activity at financial market (Figure 1). Some authors connect fast growing loan portfolio with fast coming and increasing inflation (Kancerevyčius, 2004).

The fastest growth noticed in 2005-2009, even in one year from 2005 to 2006 the growth was 38,48\%. This year was one when banks delivered the highest quantity of mortgage loans in so-called new Lithuanian bank's history. Later, loan portfolio was constantly decreasing and the biggest decline happened in 2009-2010 - up to 16,06\%.

From 2009 till 2012 total loan are decreasing because of all financial crisis consequences, but also because banks operating in Lithuania reduces lending as a response to crisis influence and altogether changed borrowing rules into more stringent and limited for customers.

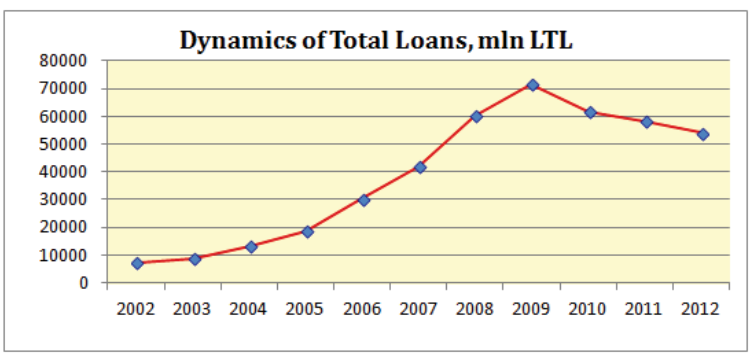

Figure 1. Dynamics of total loans in Lithuania, mln LTL.

There is opinion that banks in favorable economic times have to keep lending in optimal or so-called clever frames and in recession or bad periods have to increase it (Cooper, 2008). But, in practice, and it obviously have happened in Lithuania, banks are delivering loans easily in "good" economic periods and decreasing lending by worsening possibilities to get loans for customers in downtown of economy. As mostly have happened globally and especially in Eastern Europe countries, Central Banks didn't impose an effective qualitative and quantitative tools of money policy regulating loan market properly and in time as in prosperity periods as in recession.

A total loan portfolio can be divided into separate kinds of loans according terms that give us understanding of market priorities and also quality and credit risk of loan market (Figure 2).

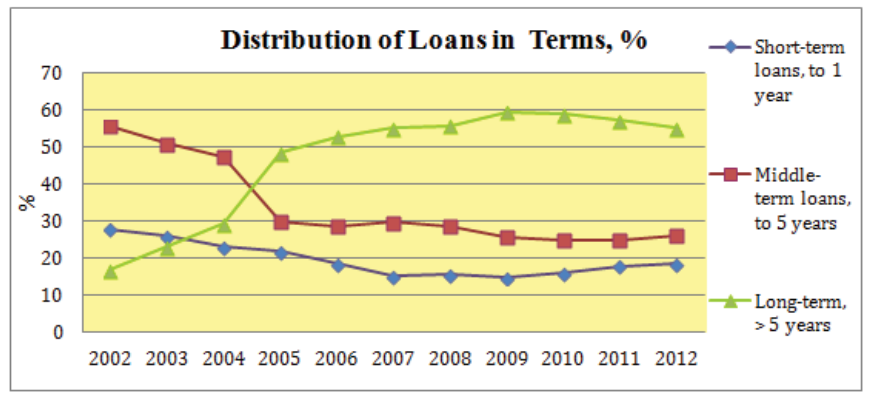

Picture 2. Dynamics of loan portfolio according terms, \%

Analyzing dynamics of short-term loans in total loan portfolio during 10 years the highest level was observed in 2002 when short-term loans consisted at 27,83\% from total loan's portfolio, after constant decreasing till 2007 year fallen down to $15,24 \%$. This decrease is connected with constant increasing of long-term loans during observed period - at the beginning of period observed the lowest part of long-term loans in total loan portfolio - 16,62\% while the nighest level of long-term loans have been in 2009 - 59,61\% and then fairly decreased till 55,40\% in 2012, but still overdominated comparatevely with short-term and middle-term loans. Part of middle-term loans during period also changed experienced almost double decline - from 55,55\% in 2002 to less than $30 \%$ at the end of period with the lowest level in 2009. 
Dealing with type of currency completely controversial tendencies are notable - part of Litas-denominated loans (LTL, Lithuanian currency, fixed rate to euro, 1 euro=3,45 LTL) dramatically decreased from 80,43\% in 2002 to $30,19 \%$ in 2012, and Euro-denominated loans increased even in one year from 16,39\% in 2002 to 29,39\% in 2003 and then with some drop happened in 2006-2007 were constantly growing (Figure 3).

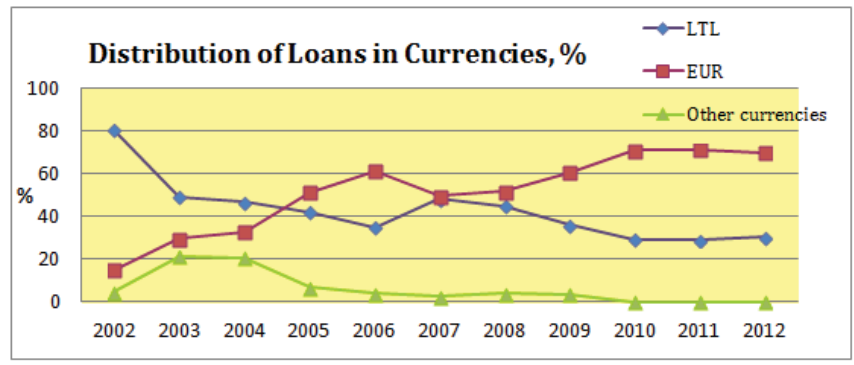

Figure 3. Dynamics of loan portfolio-according currencies, $\%$

The reason of decline in Euro-denominated loans in 2007 was increased interest rate in Euro, which jumped in average to $5,52 \%$ in 2007, i.e. 1,27 percentage points comparatively with 2006 (connected with 5 risings of base rate in 2006), also rising inflation and broken expectations about entering of Lithuania into Euro-zone in nearest year. Common tendency of growing Euro-denominated loans could be explained by lower interest rate comparatively with Litasdenominated loans with quite big difference between them - and more favorable conditions of Euro-denominated loans contracts for customers. Also it could be explained by domination of foreign banks (mostly Scandinavian) capital in Lithuanian banking sector and loan market. In 2012 Euro-denominated loans consisted 69,81\% of total loan portfolio. Loans in other-denominated currencies were not so important for Lithuanian loan market excluding the beginning of analyzed period - in $2003-2004$ years these part of loan portfolio reached $21,34 \%$ and later not exceed $4 \%$ of total loan market.

Composition of loans according customers' lines is the next one important indicator evaluating as loan market structure and its credit risk assessment as to total economic development of country (Belinskaja, Rutkauskas, 2007; Kancerevyčius, 2004). Analyzing a dynamics of distribution of loans according customers lines is obvious that the most important part of loan portfolio during all analyzed period belongs to corporate loans (Figure 4).

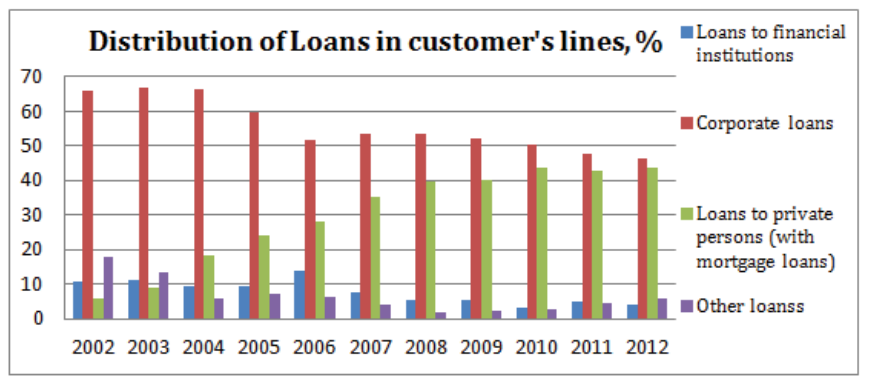

Figure 4. Distribution of Loans in customer's lines in total loan portfolio, \%

The highest indicator's ratio of corporate loans was in 2003 and consisted $66,60 \%$. Then, during all period there are controversial tendencies - declining of corporate loans and increasing of private loans in total loan portfolio. If in 2002 the relative share of private loans consisted only $5,78 \%$ of total loan portfolio, and till 2012 - this indicator constantly raised up to $43,51 \%$ and in this way almost converged to corporate loan share that was $46,50 \%$ in 2012 . Corporate loan share decreased during analyzed period as private sector got better expectations with fast growing economy accompanying with rising welfare and consumption. Other loans' including loans' to financial institutions shares didn't changed significantly during period and in overall ranges at less than $10 \%$ of total loan portfolio, but noticeably that the highest level of loans to financial institutions was in 2006 - 13,97\% (connected with so-called prosperity period in Lithuanian 
economy developments) and the lowest in 2010 - 3,16\% (connected with consequences of financial crisis).

On of the most important indicator for evaluating loan market quality and credit risk assessment is share of mortgage loans in dynamics of private loan portfolio and in total loan portfolio (Figure 5).

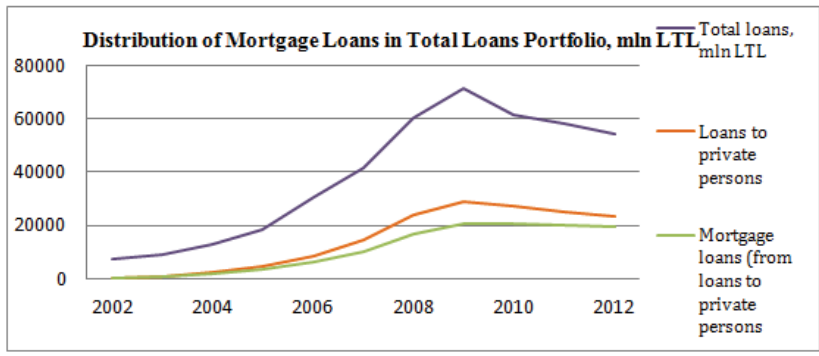

Figure 5. Distribution of Mortgage Loans in Total Loans Portfolio, mln LTL

The greatest level of all three indicators observed in 2009, year when was reached the highest level of economic development in the country. Later, all types of loans were declining, but not in the same speed. Mortgage loans raised the most in 2004 - from $727 \mathrm{mln}$ LTL up to $1909 \mathrm{mln}$ LTL comparatively to previous year and in 2006 from 3438,6 mln LTL up to $6413,5 \mathrm{mln}$ LTL. Mortgage loans decreased the most in 2011 - only up to 2,49\% comparing with 2010 year. Here is possible to see, that mortgage loans beginning from 2009 stabilized as to its volume and even comparatively with private loans that is still decreasing, and with total loans those showed significant decrease from 2009 , so is possible to presume that the most decline of total loan portfolio after crisis happened due to the reduction of corporate loans volume. Such composition and its changes in loan market during analyzed period testify from one side about quite good credit risk in private sector and from other side about borrowings potential in this sector of loans that is still remains quite big in Lithuania.

One connected indicator that shows relations between demand and dynamics of loan in longer periods is Average interest rate in dominated currencies in loan market (Figure 6.).

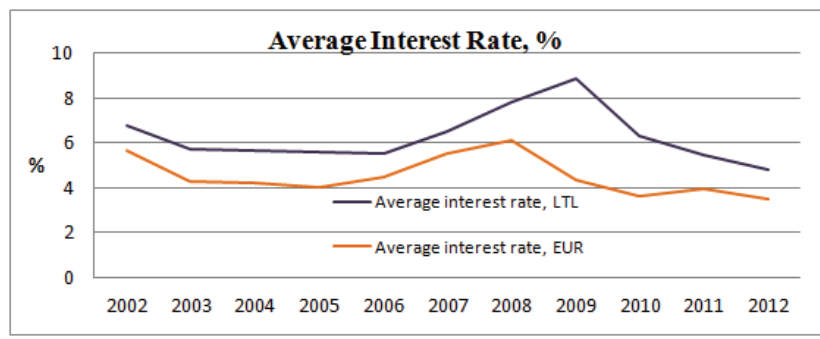

Figure 6. Average interest rate, EUR, LTL, \%

In the beginning of period average interest rate was quite high in both currencies and loan portfolio was quite small. Later, from 2002 interest rates were decreasing as loan portfolio was increasing till 2006 year. Then, interest rates were increasing together with loan portfolio in the same tendency. In 2008 Euro average interest rate reached its highest point $-6,09 \%$, and at the same time was observing a growing demand for loans that reached its highest point in 2009 and also in this year fixed the biggest level of LTL interest rate $-8,85 \%$. 2009 was the starting point for banks to change their lending policy as a reaction to financial crisis and dramatically worsening overall economical situation in the country. After, both average interest rates were declining and at the end of period consisted 3,49\% in Euro and 4,83 in LTL. Of course, also such factors were influenced on interest rates changes as policy of Central Bank of Lithuania in credit and money market, Government economical policy and decisions, inflation, demand, Balance of Payment, currency risks, EU financial policy etc. (Daigler, 1993; Douch, 1998).

Connection between loan and GDP is not less important. The ratio of these indicators help to evaluate correlation and both side influence between overall growth of Economy and bank's credit activity on the market (Figure 7). 


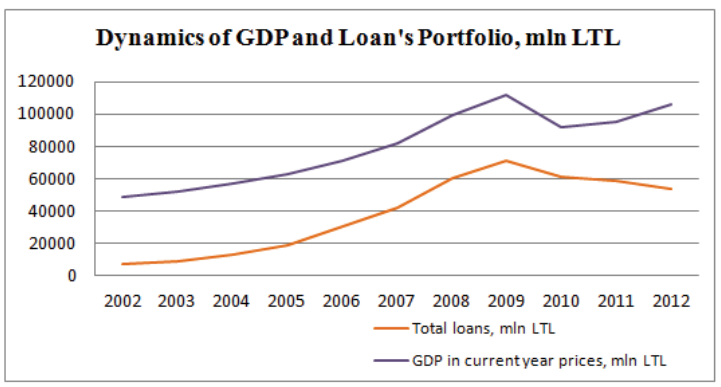

Figure 7. Dynamics of GDP and Loan's Portfolio, mln LTL

During all analyzed period and until 2011 both figures were in the same movements. It is explained by fast growing Lithuanian economy, integration into EU space, favorable possibilities for investments, good environment for speculations on real estate market, low and reducing level of unemployment, rising middle average salary, improving legal environment, positive expectations in private sector and for this reason fast growing consumption, but also by underestimated credit risk by banks and their so-called "greed for profit". The latest two years - 2011-2012 - contrary tendencies could be explained from one side with positive and strong turn of growth for Lithuanian economy and from other side still cautious behavior of banks on the credit market taking into account all lessons learned from financial crisis.

Credit risk is influenced very much on loan portfolio quality and thereby on financial stability of banking sector and all economy as well. Related indicator is common ratio or better separate ratios of Special loans provisions and Total loans; Mortgage loans and Consumption loans (Figure 8).

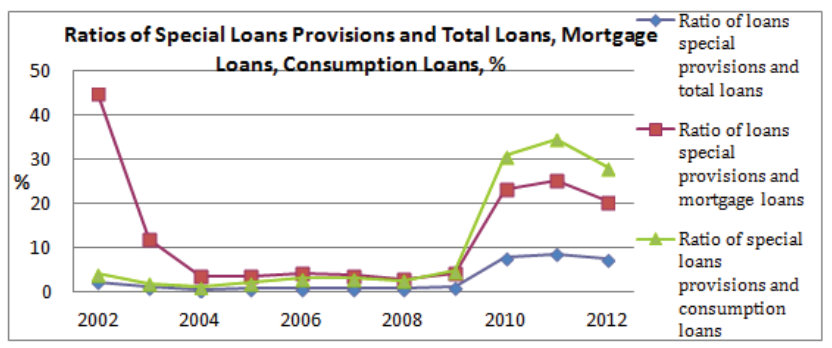

Figure 8. Ratios of Special Loans Provisions and Total Loans, Mortgage Loans, Consumption Loans, \%

Special provisions like overdue loans, non-paid loans, or measured in terms like 60 days non-paid loans etc. help to measure loan portfolio quality and its tendencies during analyzed period. Here we can see several related ratios and its changes during all period. At the beginning of period the highest ratio fixed to ratio of special provisions and mortgage loans $-44,84 \%$ which in the next year suddenly decreased to $11,84 \%$ and reached the lowest level in $2008-2,7 \%$. Such situation could be evaluated as good enough if not very good as total volume of mortgage loans constantly was increasing (Figure 5), so quality of loan portfolio and level of credit risk were on appropriate level added all other related factors. Ratio of special provisions and total loans as well as ratio of special provisions and consumption loans have been almost at the same level and in the same tendencies from 2002 to 2009 and on a comparatively low level - not exceeding 2-3,5\%, but from 2009 till 2011 raised dramatically; 34,71\% for consumption loans and 8,6\% for total loans ratios respectively. So, possible to conclude that in 2011 credit risk was the highest and quality of loan portfolio was the lowest that brought for banking sector huge losses, but this situation have happened because of credit management policy led in previous years.

Strongly related indicator for evaluating of quality of loan portfolio is Ratio of Special Provisions for Loans and Assets. As lower is indicator as better is quality of loan portfolio (Figure 9). 


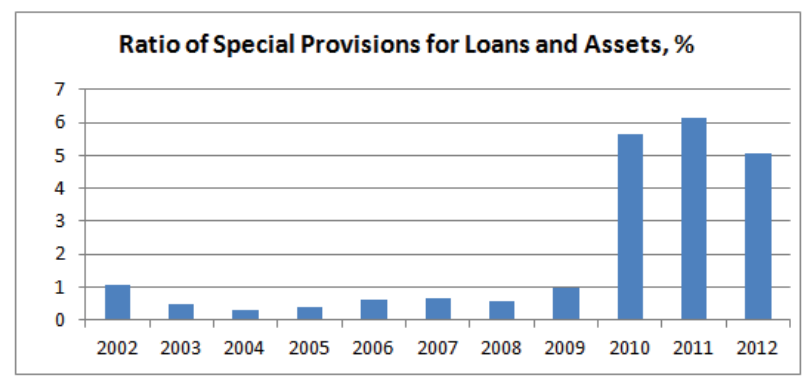

Figure 9. Ratio of Special Provisions for Loans and Assets, \%

Possibly to conclude that till 2010 quality of loan portfolio was good and credit risk was framed into proper level. The lowest indicator value was in $2004-0,31 \%$ and the highest in $2011-6,14 \%$. In latest years banks influenced by consequences of crisis and suffered from economic decline very much.

The last indicator presented in this analysis is Ratio of total loans and assets and its changes into longer period that also shows quality of credit risk management and loan portfolio financial stability (Figure 10). If loan portfolio is growing faster than assets it means that banking sector can meet liquidity problems and even bankrupt risk. As we can see, the lowest indicator observed in $2002-47,49 \%$ and then was growing constantly when reached its dangerous level in $2009-79,60 \%$. In latest years banking sector improved credit risk management using different measures and learned their lessons from previous years of operations and financial crisis.

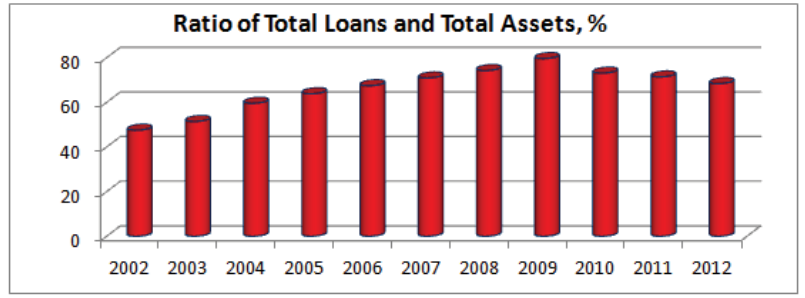

Figure 10. Ratio of Total Loans and Total Assets, \%

\section{Conclusions}

Loan market in Lithuania started to develop from 1991, but only from 2002 it developments got speed and content that is corresponded to world banking sector practice.

During analyzed period loan market in Lithuania was growing in a fast tempos from the very beginning till 2009 when loan portfolio stopped to grow and turn to quick down, at the same year interest rates dropped to quick rise and also banks faced with huge credit risk management and liquidity problems. All these events influenced on quality of loan portfolio that was getting worse and worse. In 2002 - 2005 loans market was growing because of economical fast growing and overestimated optimism for future welfare, there was loans' boom in the state during $2002-2008$ years, although because of financial crisis from 2009, loans' market recession happened.

Changes in tendencies of all analyzed indicators testify that overall economical situation and its worsening raises pressure to banks and negatively influence on borrowing and all loan market.

After the latest years of hard difficulties Lithuanian banks have been in a recovery stage from 2012 and under the latest preliminary data and estimations now situation in loan market is going better, but still quite fragile as to compare to former growth and stability: 2011-2012 is a period of loans' market stability; from 2014, a growth of loans' market is forecasted, however it is very important, that it would be temperate after all. 


\section{References}

Aleknevičienè, V. (2005). Finansai ir kreditas. Vilnius: Enciklopedija. p. 141-169.[Finance and Credit]

Altman E. I., Brady B., Resti A., Sironi A. (2002). The Link between Default and Recovery Rates:

Implications for Credit Risk Models and Procyclicality, 27 p. http://pages.stern.nyu.edu/ ealtman/Link between Default and Recovery Rates.pdf

Altman E. I. (2003). An Integrated Pricing Model for Defaultable Loans and Bonds. New York University: Leonard N. Stern School of Business. Department of Finance. Working Paper Series, No. FIN-03-009, 21 p. http://papers.ssrn.com/sol3/papers.cfm ?abstract_id=1294579\&download=yes

Bank of Lithuanaia. (2007-2013). Financial Stability review, available at http://www.lb.It/fs reviews; http://www.lb.It/financial_stability_review_2013

Belinskaja L., Galinienè B. (2010). Baltic States: from Giddy success to financial meltdown. Transformations in Business \& Economics (TIBE), Vol. 9, No 1 (19). p. 19-41.

Belinskaja L., Rutkauskas V. (2007). Būsto kainu burbulo sprogimas - problemos vertinimas. Ekonomika, Vilnius, No. 79. p. 7-27.

Bessis, J. (2002). Risk Management in Banking. 2nd Edit. West Sussex:John Wiley\&Sons.Ltd, 812 p. Bikas, E. (2013). Finansu rinkos ir depozitinès institucijos. Vilnius: Vilniaus Universitetas, 271 p. Bonner, E. А. (2008). Банковское кредитование. Москва. 159 р. [Bank Credit, in Russian].

Bickūnienè, O. (2011). Finansu teorijos pagrindai. Vilnius. 171 p. [Basic of Finance Theory, in Lith.]

Caouette, J. B., Altman, E. I., Narayanan, P. (1998). Managing Credit Risk. The next Great Financial Challenge. New York: John Wiley\&Sons, Inc. 452 p.

Colquitt, J. Credit Risk Management. Third Edition. How to Avoid Lending Disasters and Maximize Earnings. USA, 2007. p. $252-253$.

Cooper G. (2008), The Origin of Financial Crisis: Central banks, credit bubbles and the efficient market fallacy. Harriman House, London. $210 \mathrm{p}$.

Daigler, R. T. (1993). Financial Future Markets: Concepts, Evidence, and Applications. New York: Harper Collins College Publischers.

Douch, N. (1998). Managing Interest Rate Risk. Paris: ICC Publisching S. A.

Duffie, D., Singleton, K. J. (2003). Credit Risk: Pricing, Measurement and Management. Washington: Princeton University Press, p. 15 50.

Dzidzevičiūtè, L. (2010). Statistiniu vertinimo balais modeliu kūrimo ir taikymo ypatumai. Pinigu studijos, Nr. 1, p. $35-54$. http://www.lb.lt/dzidzeviciute

Girdzijauskas, Stasys. (2006). Logistinè kapitalo valdymo teorija. Determinuotieji metodai. Monografija.Vilniaus Universitetas. [Logistic theory of the capital management. Deterministic methods. Monograph, in Lithuanian].

Girdzijauskas, Stasys; Štreimikienè, Dalia; Dubnikovas, Marius. (2009). Analysing banking capital with Loglet lab software package. Transformation in Business and Economics, Vol. 8, № 2 (17), p. 45-56.

Meilè Jasienè, Giedrius Čapskas. (2008). Investigations of Dynamics and its factors of Interest rates in Lithuania in 1994-2006. Business; Theory and Practice. Vilnius Gediminas Technical University, Vilnius. 9(1). p. 33-44.

Jasevičienè, F., Ginotienè, R., Stankevičienè, V. (2000). Banku rizikos: sisteminis požiūris. Vilnius: Lietu bankininkystės, draudimo ir finansu institutas, $78 \mathrm{p}$.

Juozaitienè, L. (2000). Imonès finansai. Analizè ir valdymas. Šiauliai: Šiauliu universitetas,. 177 p. Kancerevyčius, G. (2004). Finansai ir investicijos. Kaunas: Smaltijos leidykla, 880 p.

Mituzienè, R. (2005). Finansu pagrindai. Šiauliai: Leidybos centras, 178 p. [Basic Finance, in Lith.].

Нешитой, А. С. (2007). Финансы и кредит. Москва,. 572 р. [Neshytoy, A. S. Finance and Credit, in Russian].

Panagopoulos Y., Vlamis P. (2009). Bank lending, real estate bubbles, and Basel II. Journal of real estate literature, available at: http://ehis.ebscohost.com.skaitykla.mruni.eu/ehost/pdfviewer/pdfviewer?sid=51379746-0996-4307-bb609f07a8b60765\%40sessionmgr104\&vid=2\&hid=121

Reinhart, C.M., Rogoff, K.S. (2008), Is the 2007 Sub-Prime Financial Crisis so Different? An International Historical Comparison, Harvard University, available at, http://www.economics.harvard.edu/files/faculty/51_Aftermath.pdf

Rouz, P. S. Commercial Bank Management. Producing and Selling Financial Services. Texas A\$M University, 1993. 743 p.

Statistics Lithuania (202-2013), available at, http://web.stat.gov.lt/en/

Valvonis, V. (2004). Kredito rizikos valdymas banke Pinigu studijos, Nr. 4, p. 57-82. [Credit Risk Management in banks, in Lithuanian], available at: http://lb.lt/valvonis 1

Valvonis, V. (2006). Šiuolaikinis kredito rizikos vertinimas banke: paskolos ir skolininko rizika. Pinigu studijos, Nr. 1, p. 80-104. [Modern Risk Management in Banks: loan and borrower Risk, in Lithuanian], available at: http://lb.lt/valvonis_2

Valvonis, V. (2006). Šiuolaikinis kredito rizikos vertinimas banke: paskolu portfelio rizika ir ekonominio kapitalo paskirstymas. Pinigu studijos, Nr. 2, p. 58-74. Available at: http://lb.lt/valvonis 3

Vaškelaitis, V. (2003). Pinigai: komerciniai bankai ir ju rizikos valdymas. Teorija ir praktika. Monografija. 43 knyga. Vilnius: Lietuvos mokslas. $363 p$.

Wagner, N. (2008). A View on Credit Risk - Derivatives Markets and Applications. Credit Risk Models, Derivatives and Management. Financial Mathematics Series, Vol. 6, Chapman \& Hall/CRC. New York. 